\title{
POTENSI PEMANFAATAN LIMBAH PERIKANAN DI BANDA ACEH
}

\section{Potential Use of Fisheries Waste in Banda Aceh}

\author{
*Estu Sri Luhur, Armen Zulham dan Joni Haryadi \\ Pusat Penelitian Sosial Ekonomi Kelautan dan Perikanan \\ Gedung Balitbang KP I Lt. 4 \\ Jalan Pasir Putih Nomor 1 Ancol Timur, Jakarta Utara \\ Telp: (021) 64711583 Fax: 64700924r 2015 \\ ${ }^{2}$ Pusat Penelitian Budidaya Perikanan \\ *e-mail: iansosek30@yahoo.com \\ Diterima 12 April 2014- Disetujui 25 Mei 2016
}

\begin{abstract}
ABSTRAK
Tujuan tulisan ini memaparkan hasil identifikasi dan potensi pemanfaatan limbah perikanan di Banda Aceh. Hasil kajian menunjukkan bahwa limbah yang dihasilkan dari usaha perikanan (penangkapan, budidaya, pengolahan) dan usaha non-perikanan sebagian besar belum dimanfaatkan secara optimal. Limbah yang dihasilkan dari usaha penangkapan adalah limbah padat berupa sisa ikan hasil pembongkaran dengan status sudah dimanfaatkan untuk pakan unggas. Limbah dari usaha pengolahan antara lain limbah padat berupa sisa ikan bagian kepala, isi perut dan tulang dengan status belum dimanfaatkan karena terbatasnya pengetahuan dan keterampilan dalam mengadopsi teknologi. Limbah dari usaha budidaya berupa padatan yang sudah dimanfaatkan sebagai pupuk kompos, sedangkan limbah dari budidaya kepiting soka belum dimanfaatkan. Jenis usaha yang berpotensi untuk dikembangkan dengan memanfaatkan limbah tersebut adalah: 1) Usaha tepung ikan; 2) Usaha pembuatan pakan ikan dan unggas; 3) Usaha olahan makanan ringan (snack) tulang ikan; 4) Usaha kerajinan aksesoris berupa tas atau dompet; dan 5) Usaha pembuatan tepung bahan baku citosan.
\end{abstract}

Kata Kunci: limbah perikanan, potensi, Banda Aceh

\begin{abstract}
This paper aimed to describe the identification of fisheries waste management in Banda Aceh. Results showed that waste from fisheries (catching, aquaculture, fish processing) and non-fisheries activities largely untapped optimally. Solid waste from marine captured fisheries is demolition of the remaining fish with status already used for poultry feed. Waste from processing businesses include solid waste such as leftover fish head, entrails and bone status untapped due to limited knowledge and skills in adopting technology. Waste from aguaculture in the form of solids that have been used as compost, while soft-shelled crab waste from aquaculture untapped. Type of business which have potential to be developed by utilizing the waste are: 1) Business of fish meal; 2) Business of making fish feed and poultry; 3) Business of processed snack fish bone; 4) Craft business accessories such as handbags or wallets; and 5) Business of making starch feedstock citosan.
\end{abstract}

Keywords: fisheries waste, potential, Banda Aceh

\section{PENDAHULUAN}

Buku "Economics of Natural Resources and the Environment" Pearce (1990), mengemukakan bahwa diskusi tentang limbah menjadi perhatian sejak zaman Adam Smith tokoh ekonomi klasik sampai zaman post war economist (kelompok neo klasik, dan kelompok Keynesian). Limbah merupakan distorsi ekonomi, pemikiran ini berkembang pada periode 1870 - 1970. Pada ekonom klasik distorsi limbah dapat dikendalikan dengan transaksi ekonomi berdasarkan dokrin "invisible hand", karena hal itu diyakini para pelaku ekonomi sangat rasional dan dapat mengendalikan limbah yang dihasilkan dari aktivitas ekonomi, sementara peran pemerintah hanya mengawasi dan membuat regulasi. Bagi kelompok neo-klasik, perekonomian tumbuh 
karena full employment, oleh sebab itu tingkat upah yang fleksibel merupakan faktor penting dalam pertumbuhan ekonomi, tetapi sayangnya kurang diperhatikan oleh para pelaku ekonomi. Sedangkan bagi kelompok Keynesian persoalan pertumbuhan ekonomi itu terletak pada kebijakan intervensi pemerintah yang terkait dengan pengeluaran pemerintah yang mengendalikan masalah limbah dengan penerapan pajak.

Pada tahun 1950-an ekonomi dunia tumbuh dengan strategi inovasi teknologi yang permasalahan limbah semakin mengemuka, karena dalam perekonomian berkembangnya industri. Akibatnya muncul gelombang anti pertumbuhan ekonomi pada tahun 1960. Namun pemikiran menjaga momentum pertumbuhan ekonomi dan mengendalikan permasalahan limbah, pada tahun 1970-an telah membuat kelompok ekonom lingkungan terbagi 4 kelompok, yaitu:

a. Kelompok yang mendukung pemanfaatan sumberdaya dan mendorong pertumbuhan ekonomi.

b. Kelompok yang mengendalikan pemanfaatan sumberdaya.

c. Kelompok eco-preservationis

d. Kelompok ekstrem preservationis

Perdebatan tentang limbah dan pertumbuhan ekonomi ini terus berkembang menurut mazhab dari pemikir ekonomi. Namun bagi, kelompok ekonom kapitalis dengan doktrin perekonomian keseimbangan statis mendorong pertumbuhan ekonomi diperlukan inovasi agar keseimbangan statis menemukan keseimbangan baru setelah terjadi peningkatan output yang dimaksud. Inovasi adalah internalisasi pemanfaatan limbah akibat dari pertumbuhan ekonomi tersebut. Bagi Jhingan (1999), inovasi yang demikian harus terus dikembangkan untuk menjaga momentum pertumbuhan ekonomi dan perkembangan usaha.

Dengan demikian, inovasi merupakan ciri dari ekonomi kapitalis, dimana inovasi yang dihasilkan oleh inovator harus diimplementasikan oleh entrepreneur untuk menghasilkan barang dan jasa yang baru (Syaifullah, 2011). Keberadaan inovasi dalam pemanfatan limbah pada perekonomian dapat mendorong efisiensi dan efektivitas proses produksi, sehingga inovasi diyakini menjadi motor penggerak perekonomian (Romer, 1994). Inovasi pemanfaatan limbah akan berperan dalam perekonomian, jika didukung kelembagaan yang akomodatif. Kelompok ekonom kapitalis berpandangan perkembangan ekonomi terletak pada tiga hal, yaitu: inovasi, enterpreuneur dan evolusi kelembagaan (Zuhal, 2012). Bagi kelompok ini limbah dapat dikendalikan melalui inovasi yang tepat. Selanjutnya pemikiran pemanfaat limbah sebagai input untuk menghasilkan produk baru dikembangkan oleh Pauli (2010) dalm konsep blue economy. Penerapan konsep ini dalam skala komersial dalam perekonomian menjadi sebuah tantangan.

Oleh sebab itu, untukmelakukan identifikasi limbah, perlu diketahui sumber pembangkit limbah yang terdapat dalam masyarakat. Sumber pembangkit limbah menurut Indrasti (2009) terdiri dari lima tipe, yaitu:

a. Tipe I. Bahan baku hasil pertanian yang terdiri dari komponen utama bahan yang ditransformasi menjadi produk dan komponen samping kotoran yang dibuang sebagai limbah.

b. Tipe II. Komponen utama bahan yang tidak dapat ditransformasi menjadi produk, sehingga sebagian menjadi limbah.

c. Tipe III. Komponen utama bahan yang tidak diubah menjadi produk melainkan menjadi by product.

d. Tipe IV. Bahan pembantu dalam proses transformasi bahan baku bukan menjadi bagian produk, tetapi menjadi limbah.

e. Tipe V. Produk hasil transformasi tersebut satu ketika menjadi limbah.

Dengan memahami sumber pembangkit limbah, maka upaya untuk memanfaatkan limbah akan lebih terarah, dan peluang investasi pemanfaatan limbah tersebut dapat diketahui. Pemanfaatan limbah merupakan inovasi sistim produksi bersih yang dipopulerkan oleh United Nations Environment Program (UNEP) pada tahun 1989 (UNEP, 2003). Dengan menggunakan teknologi yang adaptif dan inovatif maka limbah tersebut merupakan input untuk menghasilkan output lain dalam perekonomian. 
Usaha kelautan dan perikanan pada umumnya menghasilkan limbah padat, seperti tulang,carapas, kulit dan kepala ikan serta limbah pakan dalam perairan. Pada sisi lain usaha kelautan dan perikanan juga menghasilkan limbah cair, misalnya air tua yang tidak dimanfaatkan pada tambak garam. Pada kasus usaha perikanan tertentu seperti produksi pakan ikan, dapat juga menghasilkan limbah berupa gas. Limbah-limbah tersebut dengan teknologi yang dimiliki oleh berbagai pihak dapat ditransformasi menjadi output yang bermanfaat untuk perkembangan ekonomi masyarakat.

Tujuan tulisan ini untuk memaparkan hasil identifikasi dan potensi pemanfaatan limbah perikanan di Banda Aceh. Hasil identifikasi ini dapat menjadi masukan tingkat implementasi pengelolaan limbah perikanan pada kawasan KIMBis di Kota Banda Aceh. Informasi mengenai kegiatan usaha perikanan yang menghasilkan limbah diharapkan dapat memberikan informasi tentang peluang investasi pada pihak-pihak yang terkait untuk pemanfaatan limbah dalam rangka menerapkan teknologi dan pengembangan usaha dalam masyarakat.

Tujuan tulisan ini untuk memaparkan hasil identifikasi dan potensi pemanfaatan limbah perikanan di Banda Aceh. Hasil identifikasi ini dapat menjadi masukan tingkat implementasi pengelolaan limbah perikanan pada kawasan KIMBis di Kota Banda Aceh. Informasi mengenai kegiatan usaha perikanan yang menghasilkan limbah diharapkan dapat memberikan informasi tentang peluang investasi pada pihak-pihak yang terkait untuk pemanfaatan limbah dalam rangka menerapkan teknologi dan pengembangan usaha dalam masyarakat.

\section{METODOLOGI}

Pengumpulan data terkait dengan identifikasi potensi usaha yang menghasilkan limbah dilakukan dengan dua cara; pertama, melalui Rapid Rural Appraisal (RRA) dan survey. RRA dilakukan untuk menjaring informasi dari masyarakat tentang berbagai jenis usaha yang terdapat dalam masyarakat. Survey dilakukan pada usaha kelautan dan perikanan, dengan menggunakan daftar pertanyaan. Survey dilakukan terhadap nelayan, pembudidaya dan pengolah hasil perikanan, sedangkan RRA dilakukan, untuk menjaring potensi limbah yang terdapat pada berbagai usaha yang terdapat dalam masyarakat di luar usaha kelautan dan perikanan.

Teknik sampling yang digunakan adalah purposive sampling bagi responden perikanan tangkap dan budidaya karena populasinya cukup banyak, sedangkan untuk responden pengolahan diambil dari seluruh populasi karena jumlahnya yang terbatas. Lokasi survei dan RRA dilakukan pada 6 Kecamatan. Kecamatan tersebut adalah: Meuraxa, Kuta Alam, Kuta Raja, Syiah Kuala, Jaya Baru dan Baiturrahman. Jenis usaha meliputi usaha nelayan penangkapan ikan, usaha budidaya dan usaha pengolah serta beberapa usaha lainnya.

Kegiatan pengumpulan data dilakukan pada Bulan Agustus-September 2013. Jumlah responden yang di wawancara meliputi nelayan 40 responden, pengolah hasil perikanan 17 responden dan pembudidaya 15 responden. Selanjutnya, data primer hasil wawancara tersebut dianalisis dengan statistik sederhana untuk mengkaji potensi limbah yang dapat dimanfaatkan pada kawasan tersebut.

\section{Jenis Limbah Dari Usaha-Usaha Perikanan}

Berbagai jenis usaha dapat dijumpai pada kawasan KIMBis Banda Aceh, usaha tersebut mencakup usaha yang terkait dengan perikanan dan usaha di luar perikanan. Sebagian besar jenis usaha tersebut menghasilkan limbah yang dapat dimanfaatkan untuk menghasilkan produk baru.

Output yang dihasilkan dari limbah tersebut memerlukan teknologi dan investasi. Kedua hal ini merupakan aspek penting dari kegiatan riset aksi melalui KIMBis. Jenis usaha dan potensi limbah yang terdapat pada kawasan KIMBis Cakradonya Banda Aceh dapat dipelajari pada Tabel 1.

\section{Potensi Pemanfaatan Limbah}

Uraian berikut membahas usaha yang terdapat dalam masyarakat perikanan di Banda Aceh yang potensial dikembangkan dengan memanfaatkan limbah dari produksi mereka. Pemanfaatan limbah menumbuhkan usaha memanfaatkan limbah hasil produksi dari sumber lain, namun jika potensi itu dikembangkan dapat memperluas lapangan kerja, menumbuhkan usaha baru dalam masyarakat dan meningkatkan pendapatan. 
Tabel 1. Jenis Usaha dan Potensi Limbah di Kota Banda Aceh Tahun 2013.

\begin{tabular}{|c|c|c|c|c|}
\hline Jenis Usaha & Jenis Limbah & $\begin{array}{l}\text { Potensi Limbah } \\
\text { per hari di lokasi }\end{array}$ & Status & Potensi Pemanfaatan \\
\hline $\begin{array}{l}\text { Usaha } \\
\text { penangkapan } \\
\text { ikan }\end{array}$ & $\begin{array}{l}\text { Sisa ikan hasil } \\
\text { bongkar dari kapal } \\
\text { ke pendaratan }\end{array}$ & $\pm 50 \mathrm{Kg}$ & $\begin{array}{l}\text { Sudah dimanfaatkan } \\
\text { untuk pakan unggas }\end{array}$ & $\begin{array}{l}\text { Belum ekonomis untuk } \\
\text { tepung ikan }\end{array}$ \\
\hline \multirow[t]{2}{*}{ Usaha Ikan Kayu } & $\begin{array}{l}\text { Padatan dari sisa } \\
\text { ikan kayu (kepala } \\
\text { dan tulang) }\end{array}$ & $\pm 21 \mathrm{Kg}$ & Belum dimanfaatkan & $\begin{array}{l}\text { Belum memenuhi skala } \\
\text { ekonomis }\end{array}$ \\
\hline & $\begin{array}{l}\text { Remahan dari ikan } \\
\text { kayu kering }\end{array}$ & $\pm 3 \mathrm{Kg}$ per hari & Sudah dimanfaatkan & Untuk pakan unggas \\
\hline $\begin{array}{l}\text { Usaha Dendeng } \\
\text { ikan }\end{array}$ & $\begin{array}{l}\text { Padatan dari sisa } \\
\text { ikan (kepala dan } \\
\text { tulang ikan ) }\end{array}$ & $\pm 20 \mathrm{Kg}$ & Belum dimanfaatkan & $\begin{array}{l}\text { Potensial sebagai snack, } \\
\text { kerupuk ikan }\end{array}$ \\
\hline Usaha Abon Ikan & $\begin{array}{l}\text { Padatan dari sisa } \\
\text { ikan (kepala dan } \\
\text { tulang ikan) }\end{array}$ & $\pm 50 \mathrm{~kg}$ & Belum dimanfaatkan & $\begin{array}{l}\text { Kepala ikan untuk } \\
\text { rumah makan. Tulang } \\
\text { ikan untuk bahan } \\
\text { kerupuk ikan }\end{array}$ \\
\hline $\begin{array}{l}\text { Usaha Bakso } \\
\text { Ikan }\end{array}$ & $\begin{array}{l}\text { Padatan dari sisa } \\
\text { ikan (kepala ikan } \\
\text { dan tulang ikan) }\end{array}$ & $\pm 10 \mathrm{~kg}$ & Belum dimanfaatkan & $\begin{array}{l}\text { Tulang ikan untuk bahan } \\
\text { kerupuk ikan }\end{array}$ \\
\hline Usaha Ikan Asin & $\begin{array}{l}\text { Padatan sisa ikan } \\
\text { (kepala, kulit, isi } \\
\text { perut dan tulang) }\end{array}$ & $\pm 50 \mathrm{~kg}$ & Belum dimanfaatkan & $\begin{array}{l}\text { Kulit untuk dompet atau } \\
\text { tas. Kepala dan tulang } \\
\text { untuk tepung ikan }\end{array}$ \\
\hline $\begin{array}{l}\text { Usaha Budidaya } \\
\text { lele }\end{array}$ & $\begin{array}{l}\text { Padatan sisa pakan } \\
\text { dan lumpur }\end{array}$ & $\pm 2 \mathrm{~kg}$ & Sudah dimanfaatlan & Untuk pupuk kompos \\
\hline $\begin{array}{l}\text { Usaha Budidaya } \\
\text { Kepiting Soka }\end{array}$ & $\begin{array}{l}\text { Padatan cangkang } \\
\text { kepiting }\end{array}$ & $\pm 30 \mathrm{~kg}$ & Belum dimanfaatkan & $\begin{array}{l}\text { Untuk bahan baku } \\
\text { citosan }\end{array}$ \\
\hline
\end{tabular}

Sumber: Data primer, 2013 (diolah)

\section{Usaha Penangkapan Ikan}

Limbah dari armada penangkapan ikan sebagian besar terdiri dari limbah ikan hasil pembongkaran ikan.Limbah ini sebagian besar terdiri dari ikan pelagis kecil. Potensi limbah yang tersedia sekitar $50 \mathrm{~kg}$ per hari.Limbah tersebut saat ini dimanfaatkan untuk pakan unggas, terutama bebek. Pemanfaatan limbah untuk pembuatan tepung ikan memerlukan peralatan dan belum ekonomis.

Pemanfaatan limbah untuk tepung ikan memerlukan kajian lebih lanjut, karena limbah ikan tersebut terdiri dari berbagai jenis ikan dengan kandungan protein yang berbeda satu dengan lainnnya.

Pemanfaatan limbah untuk pakan unggas sebenarnya telah mampu menyediakan lapangan usaha bagi beberapa masyarakat pedesaan. Namun, sisa ikan tersebut akan memiliki nilai tambah yang lebih besar lagi jika diolah menjadi tepung ikan. Perlu dicatat usaha ini belum ekonomis karena diperlukan biaya yang relatif besar untuk mengumpulkan ikan sisa tersebut untuk membuat tepung ikan.

\section{Usaha Pengolahan Ikan Kayu}

Usaha pengolahan ikan kayu (keumamah) merupakan produk olahan yang menjadi ciri khas Kota Banda Aceh. Usaha ini merupakan usaha skala rumah tangga dengan jumlah pekerja rata- rata sekitar 5 sampai 6 orang (Gambar 1).

Teknologi yang digunakan adalah teknologi sederhana, menggunakan pisau, limbah yang dihasilkan usaha ini berupa limbah padatan dari sisa kulit dan tulang ikan. Limbah ini belum dimanfaatkan, tetapi limbah ini berpotensi dikembangkan menjadi bahan baku usaha tepung ikan. Limbah lain yang dihasilkan adalah remahan dari ikan kayu kering yang siap dikemas. Remahan ini juga belum dimanfaatkan secara optimal, meskipun ada yang dijual ke peternak unggas untuk dijadikan pakan.Produk turunan dari usaha pengolahan ikan kayu dapat dipelajari dari Tabel 2 


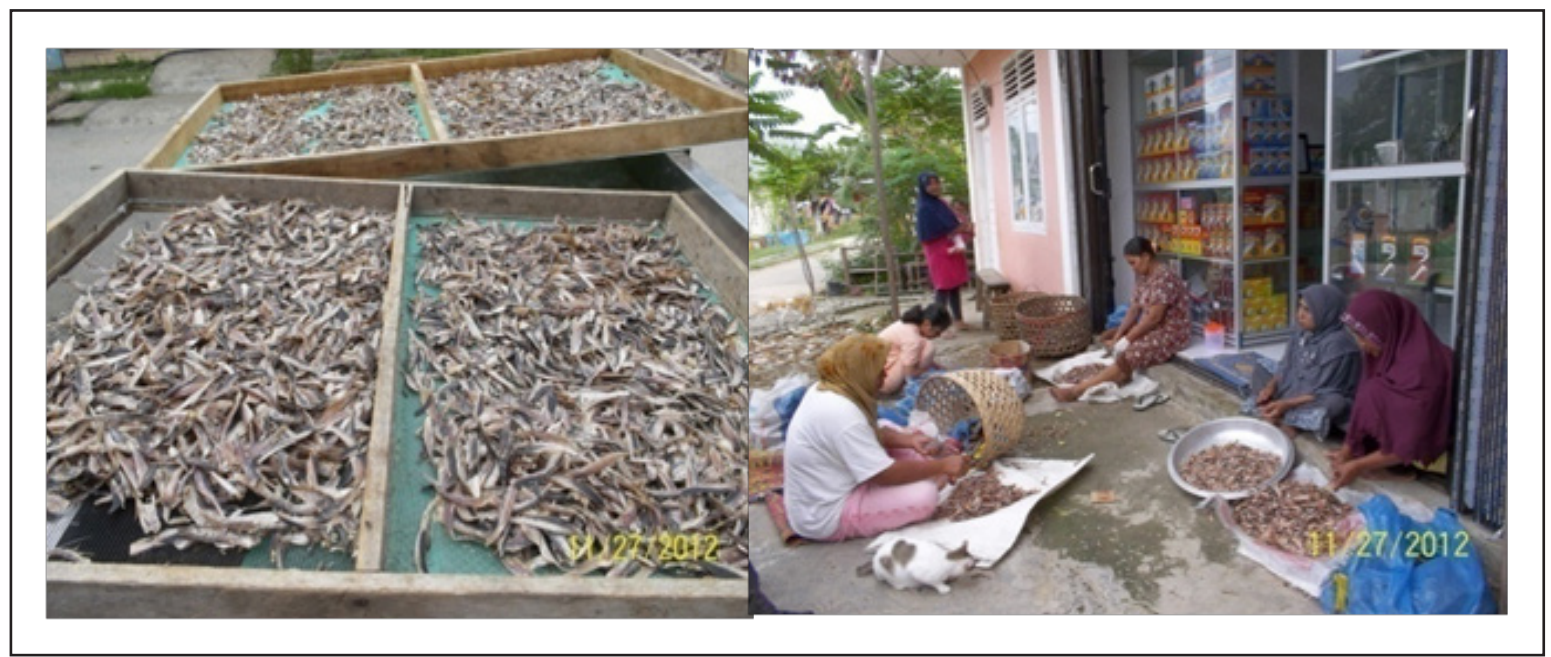

Gambar 1. Limbah Remahan Ikan dari Usaha Pengolahan Ikan Kayu di Banda Aceh

Sumber: Dok. Pribadi

Tabel 2. Karakteristik Pemanfaatan Limbah dari Hasil Penangkapan Ikan dan Usaha Pengolahan Ikan di Kota Banda Aceh, Tahun 2013.

\begin{tabular}{|c|c|c|c|c|c|}
\hline Jenis Limbah & $\begin{array}{c}\text { Tingkat } \\
\text { Ketersediaan } \\
\text { per hari }\end{array}$ & $\begin{array}{c}\text { Potensi } \\
\text { Ekonomi } \\
\text { Pemanfaatan } \\
\text { Limbah }\end{array}$ & $\begin{array}{c}\text { Jenis } \\
\text { Usaha yang } \\
\text { Memanfaatkan }\end{array}$ & $\begin{array}{c}\text { Jenis } \\
\text { Teknologi } \\
\text { Pemanfaatan } \\
\text { Limbah }\end{array}$ & $\begin{array}{c}\text { Jenis Usaha } \\
\text { Lain yang Dapat } \\
\text { Memanfaatkan }\end{array}$ \\
\hline \multicolumn{6}{|c|}{ Hasil Penangkapan Ikan } \\
\hline $\begin{array}{l}\text { Padatan ikan } \\
\text { (ikan rusak dan } \\
\text { tidak segar) }\end{array}$ & $\pm 50 \mathrm{Kg}$ & Tidak ekonomis & $\begin{array}{l}\text { Usaha pakan } \\
\text { unggas }\end{array}$ & $\begin{array}{l}\text { Teknologi tepat } \\
\text { guna }\end{array}$ & usaha tepung ikan \\
\hline \multicolumn{6}{|c|}{ Usaha Pengolahan Ikan Kayu } \\
\hline Padatan sisa ikan & $\pm 21 \mathrm{Kg}$ & $\begin{array}{l}\text { Ekonomis untuk } \\
\text { skala rumah } \\
\text { tangga }\end{array}$ & $\begin{array}{l}\text { Peternak pakan } \\
\text { ikan }\end{array}$ & $\begin{array}{l}\text { Teknologi tepat } \\
\text { guna }\end{array}$ & $\begin{array}{l}\text { Usaha tepung } \\
\text { ikan }\end{array}$ \\
\hline $\begin{array}{l}\text { Remahan Ikan } \\
\text { Kayu }\end{array}$ & $\pm 3 \mathrm{Kg}$ per hari & $\begin{array}{l}\text { Ekonomis untuk } \\
\text { skala rumah } \\
\text { tangga }\end{array}$ & $\begin{array}{l}\text { Peternak unggas } \\
\text { skala rumah } \\
\text { tangga }\end{array}$ & $\begin{array}{l}\text { Teknologi } \\
\text { Tepat guna }\end{array}$ & $\begin{array}{l}\text { Usaha tepung } \\
\text { ikan }\end{array}$ \\
\hline
\end{tabular}

Sumber: Data primer, 2013 (diolah)

Tabel 2 menunjukkan bahwa limbah remahan dari ikan kayu kering dapat dimanfaatkan sebagai bahan dalam pembuatan tepung ikan karena kadar kalsiumnya cukup tinggi. Limbah ini juga dapat dijadikan bahan untuk usaha snack ikan. Usaha yang terakhir ini belum berkembang karena limbah tersebut sangat terbatas. Hal ini disebabkan juga banyak peternak mencari limbah tersebut

\section{Usaha Dendeng Ikan}

Usaha pengolahan dendeng ikan menghasilkan, limbah padatan, kepala, perut dan tulang ikan.Usaha ini hanya memanfaatkan daging ikan. Limbah ini tersedia sekitar $20 \mathrm{~kg}$ per hari yang belum dimanfaatkan untuk menambah pendapatan bagi masyarakat lainnya..

Pada saat ini, limbah tulang ikan dicoba untuk diolah menjadi snack ikan. Untuk menghasilkan snack ikan seberat $1 / 2 \mathrm{~kg}$ memerlukan tulang ikan basah seberat $3 \mathrm{~kg}$. Oleh sebab itu untuk mengembangkan usaha menjadi skala komersial, diperlukan tulang ikan dalam jumlah yang banyak. Pada sisi lain, produk kerupuk yang berbahan baku tulang ikan ini belum dikenal oleh masyarakat setempat, walaupun upaya uji coba pemasaran produk terus dilakukan. Tabel 3, memberi gambaran tentang pemanfaatan limbah sebagai bahan baku untuk pembuatan snack tulang ikan. 
Tabel 3. Karakteristik Pemanfaatan Limbah dari Hasil Usaha Pengolahan Dendeng Ikan, Usaha Pengolahan Ikan Asin dan Budidaya Kepiting Soka di Kota Banda Aceh, Tahun 2013.

\begin{tabular}{|c|c|c|c|c|c|}
\hline Jenis Limbah & $\begin{array}{c}\text { Tingkat } \\
\text { Ketersediaan } \\
\text { Per Hari }\end{array}$ & $\begin{array}{c}\text { Potensi } \\
\text { Ekonomi } \\
\text { Pemanfaatan } \\
\text { Limbah }\end{array}$ & $\begin{array}{c}\text { Jenis } \\
\text { Usaha yang } \\
\text { Memanfaatkan }\end{array}$ & $\begin{array}{c}\text { Jenis } \\
\text { Teknologi } \\
\text { Pemanfaatan } \\
\text { Limbah }\end{array}$ & $\begin{array}{c}\text { Jenis Usaha } \\
\text { Lain yang Dapat } \\
\text { Memanfaatkan }\end{array}$ \\
\hline $\begin{array}{l}\text { Padatan ikan } \\
\text { berupa tulang ikan }\end{array}$ & $\pm 20 \mathrm{~kg}$ & $\begin{array}{l}\text { Ekonomis untuk } \\
\text { skala rumah } \\
\text { tangga }\end{array}$ & $\begin{array}{l}\text { Pengolahan } \\
\text { snack tulang } \\
\text { ikan }\end{array}$ & $\begin{array}{l}\text { Teknologi } \\
\text { tepat guna }\end{array}$ & $\begin{array}{l}\text { Rumah makan, } \\
\text { restoran, sekolah, } \\
\text { wisatawan }\end{array}$ \\
\hline Kulit ikan Asin & $\pm 50 \mathrm{~kg}$ & $\begin{array}{l}\text { Ekonomis untuk } \\
\text { skala Rumah } \\
\text { Tangga }\end{array}$ & $\begin{array}{l}\text { Usaha rumah } \\
\text { tangga }\end{array}$ & $\begin{array}{l}\text { Teknologi } \\
\text { tepat guna }\end{array}$ & Kerajinan \\
\hline $\begin{array}{l}\text { Cangkang kepiting } \\
\text { soka }\end{array}$ & $\pm 30 \mathrm{~kg}$ & $\begin{array}{l}\text { Ekonomis untuk } \\
\text { skala rumah } \\
\text { tangga }\end{array}$ & Pakan ikan & $\begin{array}{l}\text { Teknologi } \\
\text { Tepat Guna }\end{array}$ & $\begin{array}{l}\text { Industri farmasi } \\
\text { (citosan) }\end{array}$ \\
\hline
\end{tabular}

Sumber: Data primer, 2013 (diolah)

Pengolahan snack tulang ikan masih dilakukan secara tradisional tanpa menggunakan peralatan yang modern. Tenaga kerja yang akan teserap dengan adanya usaha ini sekitar 10 orang. Hasil olahan limbah ini cukup menarik bagi masyarakat karena selama ini belum pernah ada produk snack ikan berbahan baku dari tulang ikan. Pemanfaatan limbah ini masih dilakukan oleh seorang pelaku usaha saja sehingga skala ekonominya masih sangat kecil, namun peluang untuk dikembangkan sangat besar

\section{Usaha Ikan Asin}

Usaha ikan asin yang memanfaatkan ikan kambing-kambing menghasilkan limbah padatan berupa kepala, dan kulit ikan. Limbah ini hanya diperoleh saat panen melimpah. Total jumlah ketersediaan limbah padatan ini sekitar
$50 \mathrm{~kg}$ per hari. Pada musim paceklik limbah ikan kambing-kambing ini sulit diperoleh.

Selama ini limbah tersebut hanya dibuang karena dianggap tidak bermanfaat. Limbah ini sebenarnya potensial juga sebagai input dari tepung ikan. Limbah perut ikan ini berpotensi menjadi pakan ikan terutama untuk pakan ikan carnivore seperti untuk budidaya lele atau ikan gabus (Gambar 2).

Sementara itu, kulit ikan berpotensi untuk disamak dan dijadikan bahan baku pembuatan dompet atau tas. Selama ini, pemanfaatan limbah kulit ikan menjadi aksesories tidak terpikirkan oleh masyarakat karena terbatasnya pengetahuan dan keterampilan dalam mengolahnya. Karakteristik limbah dari usaha ikan Asin dilihat pada Tabel 3.

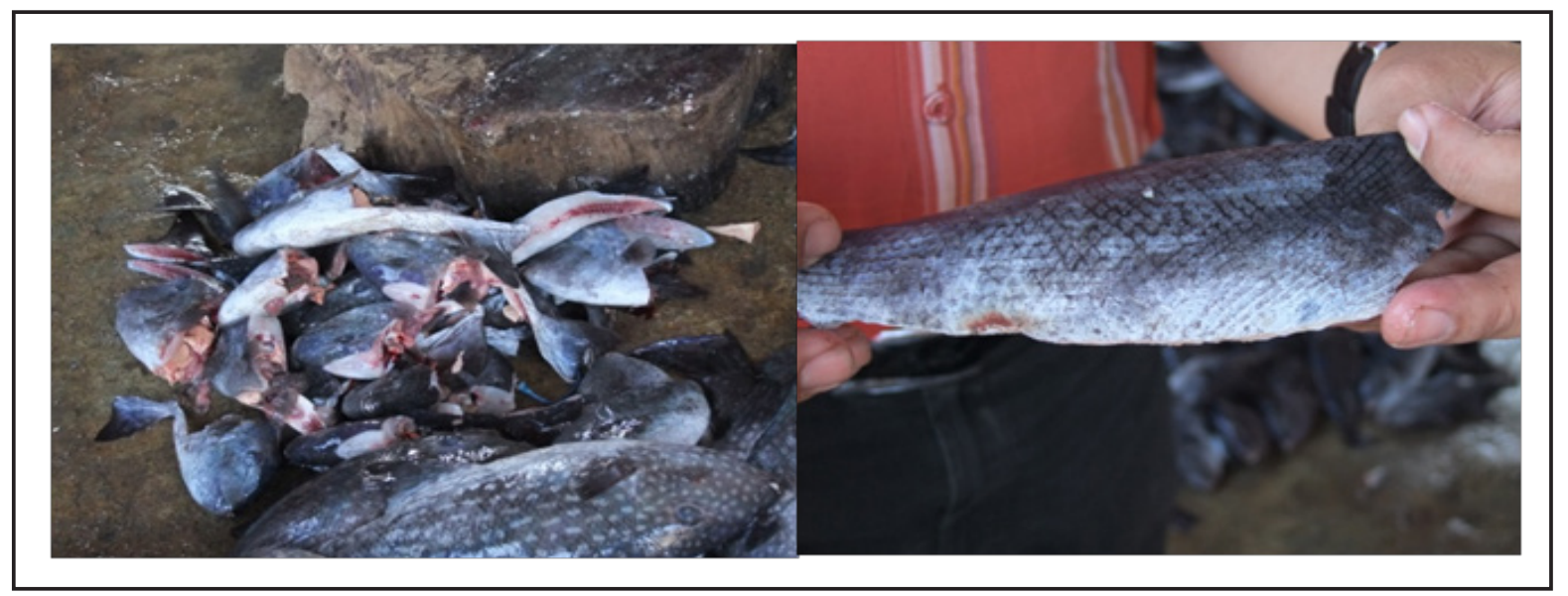

Gambar 2. Limbah Kepala, Isi Perut dan Kulit dari Usaha Ikan Asin di Banda Aceh

Sumber: Dok. Pribadi 


\section{Usaha Budidaya Kepiting Soka}

Usaha budidaya kepiting soka menghasilkan limbah padat berupa cangkang kepiting soka hasil dari moulting dan kaki dari kepiting tersebut. Limbah cangkang ini tersedia sekitar $30 \mathrm{~kg}$ per hari dalam bentuk basah. Sampai dengan saat ini, limbah cangkang kepiting ini belum dimanfaatkan karena dianggap tidak berguna dapat dilihat pada Gambar 3.

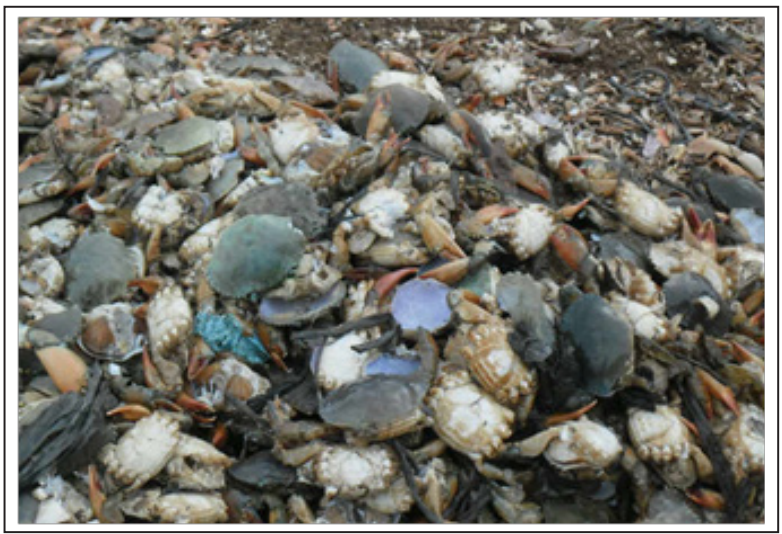

Gambar 3. Limbah Cangkang Kepiting Soka Hasil dari Budidaya Kepiting Soka. Sumber: Dok. Pribadi

Secara komersial, potensi pemanfaatan limbah ini adalah sebagai bahan baku pembuatan citosan pada industri farmasi. Berdasarkan hasil uji laboratorium yang dilakukan, kadar kalsium dalam cangkang kepiting ini sangat tinggi, yaitu mencapai $9.000 \mathrm{mg}$. Kadar kalsium tersebut sangat memenuhi syarat dalam pembuatan citosan. Selain untuk bahan citosan, tepung dari cangkang kepiting ini dapat dimanfaatkan sebagai bahan dalam pembuatan pakan ikan sehingga limbah cangkang kepiting ini dapat dipasarkan ke pabrik-pabrik pakan dan ke industri farmasi. Karakteristik usaha pemanfaatan limbah dari hasil dari budidaya kepiting soka dapat diperhatikan Tabel 3.

Usaha pemanfaatan limbah cangkang kepiting soka ini belum dikenal masyarakat, sehingga teknologi pemanfaatannya belum diketahui oleh pelaku usaha setempat. Pembuatan tepung cangkang kepiting ini dapat dilakukan secara sederha, namun terkendala dengan sulitnya memperoleh peralatan dan zat kimia yang diperlukan dalam proses perebusannya

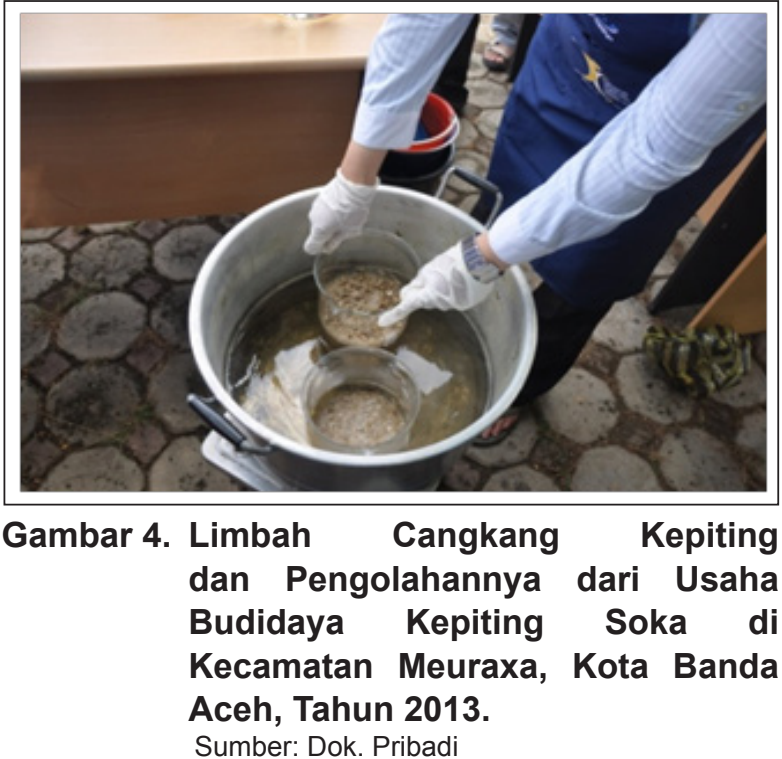

\section{KESIMPULAN DAN IMPLIKASI KEBIJAKAN}

Potensi limbah dari usaha perikanan di Banda Aceh sangat besar, berasal dari kegiatan penangkapan ikan, budidaya dan pengolahan dalam bentuk ikan rusak, ikan tidak segar, remahan ikan kayu, cangkang kepiting soka serta sisa ikan berupa kulit, isi perut dan tulang.

Limbah perikanan berpotensi untuk dimanfaatkan menjadi produk yang bernilai ekonomis. Pemanfaatan limbah dapat dilakukan dengan mengolah limbah menjadi produk lain yang berguna bagi usaha lain seperti usaha tepung ikan, usaha pembuatan pakan ikan dan unggas, usaha olahan makanan ringan (snack) tulang ikan, usaha kerajinan aksesoris berupa tas atau dompet dan usaha pembuatan tepung bahan baku citosan.

Pemanfaatan limbah yang dihasilkan oleh berbagai kegiatan pada masyarakat kelautan dan perikanan sekurang-kurangnya dapat menjadi mata pencaharaian alternatif bagi masyarakat setempat sehingga dapat memberi tambahan pendapatan.

\section{UCAPAN TERIMA KASIH}

Tulisan ini merupakan bagian dari laporan kegiatan "Pemberdayaan Masyarakat Berbasis IPTEK Mina Bisnis (KIMBis) di Banda Aceh" yang sepenuhnya dibiayai oleh Pusat Penelitian Sosial Ekonomi Kelautan dan Perikanan. 
Kami berterima kasih kepada Wakil Walikota Banda Aceh, Dinas Kelautan, Perikanan dan Pertanian Kota Banda Aceh, Balai Budidaya Air Payau (BBAP) Ujung Batee, dan Balai Besar Penelitian dan Pengembangan Pengolah Produk dan Bioteknologi Kelautan dan Perikanan (BBP4BKP) atas dukungan dan bantuannya dalam pelaksanaan kegiatan ini. Terima kasih dan apresiasi yang setinggi-tingginya juga kami sampaikan kepada rekan-rekan seperjuangan, yaitu Bapak Nawawi, Rahmat, Adi dan Isa selaku pengurus KIMBis Cakradonya di Banda Aceh. Tidak lupa terima kasih juga kami ucapkan kepada Ibu Fauziah, Ibu Salawati, Bapak Muchtar, dan Bapak Herlan selaku ketua kelompok usaha produk perikanan yang dengan semangat dan kerja kerasnya telah berpartisipasi aktif dalam kegiatan pelatihan yang dilaksanakan KIMBis Cakradonya

\section{DAFTAR PUSTAKA}

Indrasti, N. S. dan A. M. Fauzi. 2009. Produksi Bersih. IPB Press.

Jhingan, M. L. 1999. Ekonomi Pembangunan dan Perencanaan. Penterjemah D. Guritno. Cetakan ke 7. PT. Radja Grafindo Persada. Jakarta.

Pauli, G. 2010. The Blue Economy. 10 Years 100 inovations 100 Million Jobs. Paradigm Publications.
Pearce, D. W. and R. K.Turner. 1990. Economics of Natural Resources and the Envoronment. Harvester Wheatsheaf.

Romer, P. M. 1994. The Origin of Endogeneous Growth. Journal of Economic Perspectives. Vol 8 (1). Winter (1994). P3-22.

Syaifullah. 2011. Sejarah Pemikiran Ekonomi. Inovasi, Drama Asia dan Kapitalisme Amerika. (unpublish paper).

UNEP. 2003. Cleaner Production Assesment in Industries. In http://www.uneptie.ora/pc/cp/ understanding_cp/cp.industries.htm

Zuhal. 2013. Gelombang Ekonomi Inovasi. Kesiapan Indonesia Berselancar di Era Ekonomi Baru. Penerbit Gramedia Pustaka Utama. Jakarta. 